\title{
Nicotine Improves Sustained Attention in Mice: Evidence for Involvement of the $\alpha 7$ Nicotinic Acetylcholine Receptor
}

\author{
Jared W Young', Keith Finlayson*,', Christopher Spratt', Hugh M Marston ',2, Nicola Crawford', \\ John S Kelly' and John Sharkey' \\ 'Fujisawa Institute of Neuroscience, Division of Neuroscience, University of Edinburgh, Edinburgh, UK
}

\begin{abstract}
In humans, nicotine has been shown to improve attention in both normal and impaired individuals. Observations in rats reflect some, but not all aspects of the nicotine-induced improvements in humans. To date these findings have not been replicated in mice. To examine the effect of nicotine on sustained attention in mice, we have established a version of the 5-choice serial reaction-time (5-CSR) task with graded levels of difficulty, based upon spatial displacement and a variable intertrial interval. Using this paradigm, microgram doses of nicotine produced a consistent reduction in the level of omissions and an improvement in proportion correct in normal mice. This improvement in sustained attention was made irrespectively of whether mice had previously received nicotine. In an attempt to elucidate which nicotinic acetylcholine receptor (nAChR) subtype(s) mediate this effect, we examined the performance of $\alpha 7 \mathrm{nAChR}$ knockout (KO) mice in the 5-CSR task. $\alpha 7 \mathrm{nAChR}$ KO mice not only acquired the task more slowly than their wild-type littermates, but on attaining asymptotic performance, they exhibited a higher level of omissions. In conclusion, by increasing the level of task difficulty, the performance of mice was maintained at sufficiently low levels to allow a demonstrable improvement in performance upon nicotine administration. Furthermore, as $\alpha 7 \mathrm{KO}$ mice are clearly impaired in the acquisition and asymptotic performance of this task, the $\alpha 7$ $\mathrm{nAChR}$ may be involved in mediating these effects of nicotine.

Neuropsychopharmacology (2004) 29, 89 I-900, advance online publication, 18 February 2004; doi: I 0. I 038/sj.npp. I 300393
\end{abstract}

Keywords: nicotine; mice; attention; receptors; nicotinic ( $\alpha 7)$; knockout

\section{INTRODUCTION}

It has been proposed that attentional dysfunction may underlie the psychopathology of schizophrenia (Cullum et al, 1993; Cornblatt and Keilp, 1994). In humans, attentional performance is generally assessed using the continuous performance test (CPT), where subjects have to attend to visual stimuli over a sustained period of time (Levin et al, 1998; White and Levin, 1999; Shytle et al, 2002). Nicotine, the predominant psychoactive compound in tobacco smoke, has been shown to enhance sustained attention in normal humans by reducing omission levels (Levin et al, 1998). Moreover, it has been suggested that nicotine can lock the brain into an attentional processing mode whereby there are fewer lapses in attention and

\footnotetext{
*Correspondence: Dr K Finlayson, Fujisawa Institute of Neuroscience, Division of Neuroscience, University of Edinburgh, I George Square, Edinburgh, EH8 9JZ UK, Tel: + 44 131 650 8491, Fax: + 44131667 938।, E-mail: Keith.Finlayson@ed.ac.uk

'Present address: Organon Laboratories, Newhouse, Lanarkshire, MLI $5 \mathrm{SH}$ UK.

Received 20 October 2003; revised 15 December 2003; accepted 18 December 2003

Online publication: 23 December 2003 at http://www.acnp.org/ citations/Npp 12230303480/default.pdf
}

therefore less omissions (Mancuso et al, 1999). These observations may underlie the ability of nicotine to enhance attention and improve the symptomatology of various human diseases including schizophrenia (Yang et al, 2002), Alzheimer's disease (White and Levin, 1999), attention deficit hyperactivity disorder (Shytle et al, 2002), Parkinson's disease (O'Neill et al, 2002), and Tourette's syndrome (Sanberg et al, 1997).

The identity of the nicotinic acetylcholine receptor (nAChR) subtype(s) mediating the beneficial effects of nicotine on cognition has yet to be elucidated. Currently, nine genes have been described that encode neuronal $\mathrm{nAChR}$ subunits in mammals $(\alpha 2-\alpha 7, \beta 2-\beta 4)$, with $\alpha 9$ and $\alpha 10$ subunits also found in mammalian cochlea. The majority of subunits appear capable of forming heteromeric channels, with the number of combinations identified in tissue continually increasing (Le Novere et al, 2002). In rodent brains, the two most predominant nAChRs appear to be the heteromeric $\alpha 4 \beta 2 \mathrm{nAChR}$, and the homomeric $\alpha 7$ nAChR, accounting for 85 and $10 \%$ of neuronal nAChRs respectively (Clarke et al, 1985). In rats, the roles that these receptors play in sustained attention is examined using the 5-choice serial reaction-time (5-CSR) task (Mirza and Stolerman, 1998; Grottick and Higgins, 2000; Stolerman et al, 2000; Mirza and Bright, 2001; Hahn et al, 2002, 
2003a,b; Terry et al, 2002; Grottick et al, 2003). While nicotine-induced improvements in sustained attention have been reported in the rat literature, these studies have generally required the additional complexities afforded by brain lesions, poorly performing subjects, or task challenges (Muir et al, 1995; Grottick and Higgins, 2000; Hahn et al, 2002). Indeed, no consistent improvements have been reported in unimpaired rats (Mirza and Bright, 2001; Terry et al, 2002). Clear identification of the receptor subtypes underlying the beneficial effects of nicotine is made more onerous (Shoaib et al, 2002) by the current lack of truly selective compounds and the difficulties associated with producing nAChR subtype selective drugs (Gotti et al, 2000; Broad et al, 2002). It has therefore been suggested that a combined approach of pharmacological interventions and transgenic animals may help delineate the nAChR subtypes involved (Gotti et al, 2000; Chapman, 2002).

Since its first description by Carli et al (1983), the 5-CSR task has been extensively used in rat studies. In contrast, the task has received only limited, and comparatively recent attention in mice (Humby et al, 1999; Marston et al, 2001). Hitherto, no reports addressing the effects of nicotine on the performance of mice in the 5-CSR task have been published. In the present study, we describe the development and use of a version of the 5-CSR task to examine the hypothesis that nicotine can improve attentional function in mice by primarily reducing omission levels and secondarily by increasing proportion correct. In addition, the role that the $\alpha 7 \mathrm{nAChR}$ plays in attention was examined by using $\alpha 7$ knockout (KO; B6.12957-Chrna7 ${ }^{\text {tmlbay }}$, Orr-Urtreger et al, 1997) mice in the task, who should conversely exhibit a deficit as measured by increased omission levels and a lower proportion correct score. Some of the current findings have previously been presented in abstract form (Young et al, 2003).

\section{MATERIALS AND METHODS}

\section{Animal Maintenance and Genotyping}

Two groups of C57 Bl/6J male mice (study 1, $n=16$; study 2, $n=25$, Charles River, Margate, UK), weighing between 22 and $26 \mathrm{~g}$ at the start of the studies, were used in the behavioral paradigms described. Eight $\alpha 7$ nAChR KO (B6.12957-Chrna7 ${ }^{\text {tmlbay }}$; The Jackson Laboratory, Bar Habor, USA) and eight age-matched wild-type littermates (WT; N8F1 and F2), weighing between 22 and $27 \mathrm{~g}$ at the inception of the study, were used in study 3. For confirmation of genotype, transgenic animals were tail tipped under halothane/nitrous oxide anesthesia, and DNA obtained by proteinase $\mathrm{K}$ treatment of tail samples (Promega, Southampton, UK; Sambrook and Russell, 2001). The PCR protocol used was as described on the Jackson Laboratory website (www.jax.org). All animals were group housed (where possible) in a temperature controlled room $\left(21 \pm 1^{\circ} \mathrm{C}\right)$, with a $12 \mathrm{~h}$ light/dark cycle (lights on at 0730) and were tested during the light phase of the cycle. Mice were maintained at $85 \%$ of their free-feeding weight and were permitted free access to water during training and testing. The animals were given ad libitum access to food approximately every 5 weeks in order to re-establish a freefeeding weight. Studies were performed under license by UK authorities (Scientific Animal Procedures Act, 1986, http://www.homeoffice.gov.uk), and in accordance with the Guide for the Care and Use of Laboratory Animals as adapted and promulgated by the National Institute of Health.

\section{Tissue Procurement and $\mathrm{P}_{2}$ Synaptosomal Membrane Preparation}

For radioligand binding studies, $\mathrm{P}_{2}$ synaptosomal membranes were prepared as described previously (Maemoto et al, 1997). Mice were killed by cervical dislocation, the brains removed, and immediately placed in ice-cold saline $(0.9 \% \mathrm{NaCl})$. The whole brain minus cerebellum (due to the low density of $\alpha 7$ nAChRs) was used for preparation of synaptosomal membranes. Brain tissue from each animal was treated independently in the $\alpha 7 \mathrm{nAChR}$ KO study. Tissue samples were homogenized in 15 volumes ( $15 \mathrm{vol})$ of ice-cold $\left(4^{\circ} \mathrm{C}\right) \quad 0.32 \mathrm{M}$ sucrose using a glass/Teflon homogenizer, centrifuged at $1000 \mathrm{~g}$ for $10 \mathrm{~min}\left(4^{\circ} \mathrm{C}\right)$, and the resulting supernatant centrifuged at $17000 \mathrm{~g}\left(20 \mathrm{~min}, 4^{\circ} \mathrm{C}\right)$. The synaptosomal/mitochondrial $\mathrm{P}_{2}$ pellet was lysed in $30 \mathrm{vol}$ of ice-cold $\left(4^{\circ} \mathrm{C}\right)$ milliQ $\mathrm{H}_{2} \mathrm{O}$ for $60 \mathrm{~min}$ and centrifuged at $50000 \mathrm{~g}\left(10 \mathrm{~min}, 4^{\circ} \mathrm{C}\right)$. The membrane pellet was then resuspended in $30 \mathrm{vol}$ of ice-cold $\left(4^{\circ} \mathrm{C}\right) 50 \mathrm{mM}$ potassium phosphate assay buffer $(50 \mathrm{mM}$ potassium phosphate, $1 \mathrm{mM}$ EDTA, and $0.01 \%$ sodium azide, $\mathrm{pH}$ $7.4)$, centrifuged at $50000 \mathrm{~g}$ for $10 \mathrm{~min}\left(4^{\circ} \mathrm{C}\right)$ and resuspended in $5 \mathrm{vol}$ (original tissue weight) of assay buffer and stored at $-20^{\circ} \mathrm{C}$. On the day of use, frozen membranes were thawed, diluted to $30 \mathrm{vol}$ with ice-cold $\left(4^{\circ} \mathrm{C}\right)$ assay buffer and the suspension centrifuged at $50000 \mathrm{~g}$ for $10 \mathrm{~min}$ at $4^{\circ} \mathrm{C}$. The pellet was then resuspended in the appropriate volume of assay buffer and the protein content determined as described previously (Finlayson et al, 2001).

\section{Behavioral Apparatus}

Training and testing took place in 'nine-hole' operant chambers $(25 \times 25 \times 25 \mathrm{~cm}$, Cambridge Cognition, Cambridge, UK). The response holes were used in two configurations; 'narrow' with holes 3-7 open and 1, 2, 8, and 9 occluded, or 'wide' with holes $1,3,5,7$, and 9 open and $2,4,6$, and 8 closed. The mice were required to respond to a visual stimulus recessed into the holes, with a nose poke. A response was detected by an infrared beam crossing the entrance of each hole. Liquid reinforcement in the form of strawberry milkshake (Yazoo ${ }^{\circledR}$; UK; $20 \mu \mathrm{l}$ ) was delivered by a peristaltic pump to a spigot located within the magazine at the chamber front, on the wall opposite to the nine-hole array. Entry into the magazine was monitored by an infrared beam. The house light was set into the roof of the operant chamber, which was housed within a soundattenuating box containing a fan, which provided ventilation and a constant low background noise. An infrared camera was installed within each box allowing performance to be monitored during testing. Each operant chamber was interfaced to an Acorn computer (RISC OS). The software required was programmed in house using the Arachnid extension to BBC Basic (Paul Fray Ltd, Cambridge, UK). 


\section{Behavioral Handling and Procedures}

For the 3 days prior to training, all mice were handled for approximately $10 \mathrm{~min}$ per day. On the day before initiation of training mice were introduced to the liquid reinforcer. On training days 1 and 2, mice were placed in the nine-hole boxes for $10 \mathrm{~min}$, during which liquid reinforcement was dispensed every $15 \mathrm{~s}$ into the well of the magazine, while the magazine was lit. Entry into the magazine caused the light to be extinguished until the next reinforcement was delivered. At the end of this and subsequent sessions, the wells beneath the spigots were inspected to ensure no liquid was present. On day 3 , in order to obtain reinforcement, mice were required to nose poke in any of the 5 lit holes at the rear of the chamber. This process was repeated every day until all mice were able to make at least 60 responses to the light cue within a 25 min session.

\section{5-CSR Task}

At the beginning of each session the house light was extinguished and the magazine was lit. A nose poke in the magazine initiated the trial sequence. An intertrial interval (ITI) of $2 \mathrm{~s}$ preceded one of the five response holes being illuminated. To record a correct response the mouse had to respond within a stimulus duration (SD) period of $10 \mathrm{~s}$, or during the following $2 \mathrm{~s}$ limited hold (LH) when the light was extinguished. The magazine light was then illuminated, a reinforcement dispensed, with entry in to the magazine initiating a $4 \mathrm{~s}$ reward interval (RI). Failure to respond during the $\mathrm{SD}+\mathrm{LH}$ resulted in an 'omission' error being recorded and a $4 \mathrm{~s}$ time out (TO) initiated. During a TO the house light was on and all holes were unresponsive, then as the TO phase ended the house light was extinguished, and the magazine illuminated. The mouse could then begin a new trial by responding in the magazine. If, during the choice phase, the mouse responded in a hole other than the one that was lit, the response was registered as an incorrect response and a TO phase began. If the mouse responded during the ITI, an anticipatory error was recorded and a TO phase initiated. Each session lasted $25 \mathrm{~min}$, or 120 trials if completed sooner. The SD was initially set at $10 \mathrm{~s}$ and was only reduced to $8 \mathrm{~s}$ following attainment of a mean correct latency half that of the SD and a minimum of 10 correct responses per session, maintained for over two consecutive sessions. The SD was further reduced to 4,2 , and then $1 \mathrm{~s}$ based upon these response latency criteria. Successful acquisition of the task was defined as attainment of a $1 \mathrm{~s} \mathrm{SD,} \mathrm{a} \mathrm{proportion} \mathrm{correct} \mathrm{score} \mathrm{(correct/correct} \mathrm{+}$ incorrect + anticipatory errors) of $>0.8$, and with \% omissions (omissions/correct + incorrect + omissions) of $<40 \%$. In study 3 , once every mouse had attained acquisition criteria, the mice were trained continuously until asymptotic performance had been established. In studies 1 and 2, once every mouse had attained acquisition criteria, a variable (2-10 s) ITI was introduced, and mice were trained continuously until asymptotic performance had been established. The mice were allocated to a drug group in a counter-balanced design. Each mouse received saline for the three training sessions prior to testing, and then given their allocated nicotine dose everyday in the four subsequent test sessions. The effects of subcutaneous (-)nicotine hydrogen tartrate (Sigma, Poole, UK) on performance (study $1 ; 3,30$, and $300 \mu \mathrm{g} / \mathrm{kg}$; study $2 ; 1,10$, and $100 \mu \mathrm{g} / \mathrm{kg}$ ) were assessed $10 \mathrm{~min}$ after drug injection, with nicotine prepared freshly everyday.

\section{$\left[{ }^{3} \mathrm{H}\right]$ Methyllycaconitine $\left(\left[{ }^{3} \mathrm{H}\right] \mathrm{MLA}\right)$ Binding to the $\alpha 7$ nAChR}

$\left[{ }^{3} \mathrm{H}\right]$ MLA (19.8 Ci/mmol; Tocris, Bristol, UK) binding to the $\alpha 7 \mathrm{nAChR}$ was carried out as previously described (Davis et al, 2000). Binding assays were conducted in a total volume of $250 \mu \mathrm{l}$; consisting of 50 or $100 \mu \mathrm{l}$ (no drug present) of potassium phosphate assay buffer, $50 \mu \mathrm{l}$ of test drug, $50 \mu \mathrm{l}$ of $\left[{ }^{3} \mathrm{H}\right]$ MLA (final concentration approximately $2 \mathrm{nM}$ ), and $100 \mu \mathrm{l}$ of membrane suspension. Test compounds (methyllycaconitine and $( \pm)$ epibatidine, Tocris, Bristol, UK; $(-)$ nicotine hydrogen tartrate and d-tubocurarine chloride, Sigma, Poole, UK) were prepared by serial dilution in assay buffer. Nonspecific binding was determined in the presence of $1 \mathrm{mM}$ d-tubocurarine. Binding was initiated by the addition of membranes, and samples were incubated for $60 \mathrm{~min}$ at $25^{\circ} \mathrm{C}$. Binding was terminated by filtration onto glass fiber filters (GF/B, Whatman; presoaked for $3 \mathrm{~h}$ in $0.3 \%$ polyethylenimine) using a Brandel cell harvester, followed by three rapid $(1 \mathrm{ml})$ washes with ice-cold phosphatebuffered saline $\left(20 \mathrm{mM} \mathrm{Na}_{2} \mathrm{HPO}_{4}, 5 \mathrm{mM} \mathrm{K \textrm {K } _ { 2 }} \mathrm{PO}_{4}, 150 \mathrm{mM}\right.$ $\mathrm{NaCl}, \mathrm{pH}$ 7.4). Filter disks were transferred to RT30 tubes (Sterling, UK) and radioactivity determined using a Packard 2500TR liquid scintillation counter.

\section{Data Analysis}

The main dependent behavioral variables selected for analysis were: (a) \% omissions, (b) proportion correct, and (c) mean correct latency (cumulative correct latency/ correct). As the proportion correct in studies 1 and 3 was not normally distributed, the data were arcsine transformed. However, in Figures $1 \mathrm{~b}$ and $3 \mathrm{~d}$ raw data are presented. Each variable in studies 1 and 2 were compared to the mean scores obtained with saline using a three-way ANOVA (dose, day, and ITI time), with Tukey post hoc analysis. Acquisition performance in study 3 was analyzed by assessing the increase in proportion correct across sessions per subject, and the data fitted using a fourparameter logistic. The number of sessions required to attain 0.50 proportion correct $\left(\mathrm{A}_{50}\right)$ was calculated for each subject, and compared between the groups using a $t$-test. Asymptotic performance in study 3 was compared using a two-way repeated measures ANOVA (genetic make-up and day). All statistics were performed using Sigma Stat (v. 2.03, SPSS, USA). For the $\left[{ }^{3} \mathrm{H}\right]$ MLA binding studies, data were analyzed using Sigma Plot 8.0 (Jandel, USA) and ligand affinities $\left(K_{\mathrm{D}} / K_{\mathrm{i}}\right)$ were calculated as described previously (Finlayson et al, 2001).

\section{RESULTS}

Study 1 - The Effect of Nicotine $(3,30$, and $300 \mu \mathrm{g} / \mathrm{kg}$ ) on Mouse 5-CSR Task Performance

Initially, a pilot study was conducted in which mice $(n=16)$ were trained to perform the 5-CSR task using a less 

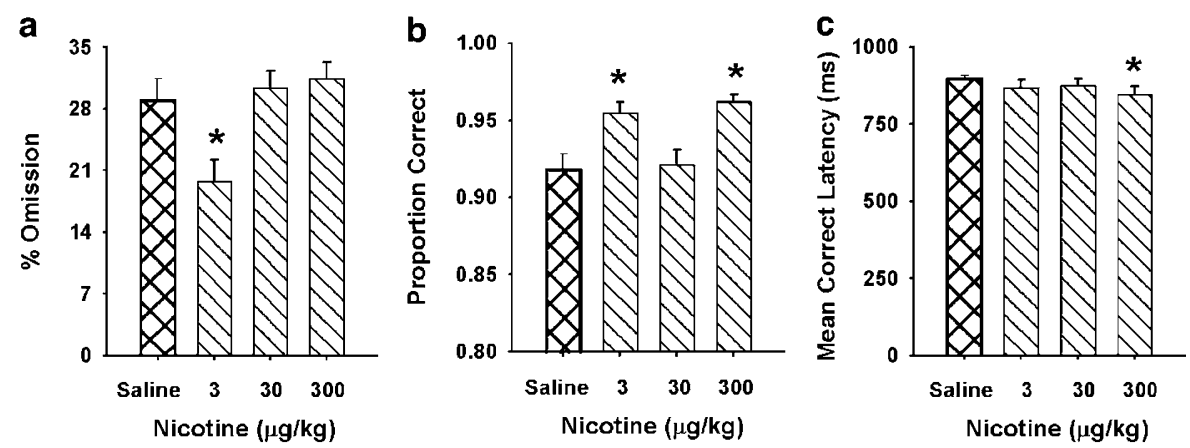

Figure I Effects of nicotine on the performance of mice in the modified 5-CSR task. Each mouse in this study had undergone extensive training and had received nicotine (s.c.) injections 3 weeks prior to testing. The mice were separated into four groups in a counter-balanced design and given saline for three prior training sessions (Thursday, Friday, and Monday), followed by their allocated dose for 4 consecutive days (Tuesday-Friday). The $3 \mu g / k g$ dose of (-)nicotine significantly reduced \% omissions (a) and increased proportion correct (b) without altering mean correct latency (c). In contrast, $300 \mu \mathrm{g} / \mathrm{kg}$ of $(-)$ nicotine reduced mean correct latency (c) and increased proportion correct (b), without affecting \% omissions (a). The $30 \mu \mathrm{g} / \mathrm{kg}$ dose of (-)nicotine had no effect on any measure. Doses of nicotine that produced significant effects compared to saline on these measures are marked $(* p<0.05)$, with data shown as mean $\pm \mathrm{SEM}$.

demanding narrow array (holes 3-7), with animals subsequently administered saline or three different doses of nicotine $(3,30$, and $300 \mu \mathrm{g} / \mathrm{kg})$. The mice were tested according to a Latin-square design over a 10-week period. Each 4-day dosing period was separated by a 10-day washout period, during which a baseline response to saline was re-established. No overall statistical difference was seen with any dose of nicotine examined (data not shown). However, as the mice had performed at near optimum levels (proportion correct approximately equal to 0.96 ), any clear enhancement in performance would be difficult to detect. The task was subsequently modified to increase the level of difficulty by using a wide array (holes $1,3,5,7$, and 9) and by varying the ITI $(2-10 \mathrm{~s}$ instead of a constant $2 \mathrm{~s})$. Such modifications have previously been used to increase task difficulty in human sustained attention tasks (Bates et al, 1995). These modifications differ from the acute challenges utilized for rats as they are employed in both training and testing days (Hahn et al, 2002). Following a 3-week washout period mice were again administered saline or nicotine (3, 30 , and $300 \mu \mathrm{g} / \mathrm{kg}$ ). As can be seen in Figure $1 \mathrm{a}$, the $3 \mu \mathrm{g} / \mathrm{kg}$ dose of nicotine produced a significant reduction in \% omissions and in Figure 1b, an increase in proportion correct when compared to the control group. A three-way ANOVA with nicotine dose, ITI time, and day as betweensubject factors, yielded significant main effects of: nicotine dose on $\%$ omissions $(\mathrm{F}(3,36)=17.4, p<0.001)$, proportion correct $(\mathrm{F}(3,36)=8.83, p<0.001)$, and mean correct latency $(\mathrm{F}(3,36)=5.27, \quad p=0.004)$; ITI time on $\%$ omissions $(\mathrm{F}(3,36)=28.2, p<0.001)$, and on mean correct latency $(\mathrm{F}(3,36)=57.8, \quad p<0.001) ;$ day on proportion correct $(\mathrm{F}(3,36)=5.15, p=0.005)$. Tukey post hoc analysis on nicotine dose revealed a significant effect of $3 \mu \mathrm{g} / \mathrm{kg}$ nicotine on $\%$ omissions (Figure 1a) $(\mathrm{F}(3,36)=17.4, p<0.001)$, and on proportion correct (Figure $1 \mathrm{~b})(\mathrm{F}(3,36)=8.83, p<0.05)$. Nicotine at $300 \mu \mathrm{g} / \mathrm{kg}$ also increased proportion correct (Figure $1 \mathrm{~b})(\mathrm{F}(3,36)=8.83, p=0.001)$, and decreased mean correct latency (Figure 1c) $(\mathrm{F}(3,36)=5.27, p<0.005)$, but had no significant main effect on \% omissions (Figure 1a). However, no effect was observed at the intermediate nicotine dose of $30 \mu \mathrm{g} / \mathrm{kg}$ on any of the parameters examined.

\section{Study 2 - The Effect of Nicotine $(1,10$, and $100 \mu \mathrm{g} / \mathrm{kg})$ on 5-CSR Task Performance in Drug-Naive Mice}

As study 1 was performed in mice that had previously been exposed to nicotine on a repeated basis, the significant improvements observed in performance could have been confounded by factors such as receptor upregulation. Indeed, our studies suggest that a 1-week washout period with saline following nicotine administration is not always sufficient to ensure a return to baseline performance (data not shown). We therefore examined the cognitive effects of nicotine using the modified 5-CSR task and drug-naive mice. As the $3 \mu \mathrm{g} / \mathrm{kg}$ dose of nicotine had produced the most robust improvement in performance we examined the effect of nicotine at 1,10 , and $100 \mu \mathrm{g} / \mathrm{kg}$. All three doses of nicotine produced a reduction in the levels of $\%$ omissions when compared to the control group (Figure 2a). A threeway ANOVA with nicotine dose, ITI time, and day as between-subject factors, yielded significant main effects of: nicotine dose on $\%$ omissions $(\mathrm{F}(3,36)=212, p<0.001)$, proportion correct $(\mathrm{F}(3,36)=3.285, p=0.032)$, and mean correct latency $(\mathrm{F}(3,36)=13.3, p<0.001)$; ITI time on $\%$ omissions $(\mathrm{F}(3,36)=40.4, p<0.001)$, proportion correct $(\mathrm{F}(3,36)=3.512, p=0.016)$, and on mean correct latency $(\mathrm{F}(3,36)=9.83, \quad p<0.001) ; \quad$ day on $\%$ omissions $(\mathrm{F}(3,36)=6.58, p=0.001)$. Tukey post hoc analysis on nicotine dose revealed significant effects of 1,10 , and $100 \mu \mathrm{g} / \mathrm{kg}$ nicotine on $\%$ omissions $(\mathrm{F}(3,36)=22.6, p<0.001$ for each dose Figure 2a). Moreover the $1 \mu \mathrm{g} / \mathrm{kg}$ dose of nicotine significantly increased proportion correct (Figure $2 \mathrm{~b}$ ) and the $10 \mu \mathrm{g} / \mathrm{kg}$ dose significantly altered mean correct latency (Figure 2c). There were significant main effects of the $1 \mu \mathrm{g} / \mathrm{kg}$ dose of nicotine on proportion correct $(\mathrm{F}(3,36)=3.29, p=0.05)$, and the $10 \mu \mathrm{g} / \mathrm{kg}$ dose significantly increased mean correct latency $(F(3,36)=13.3$, $p<0.05)$.

\section{Study 3 - The Effect of $\alpha 7 \mathrm{nAChR}$ KO on Mouse Performance in the 5-CSR Task}

The debate over which nicotinic receptor subtypes are responsible for the cognitive effects of nicotine is far from 
a

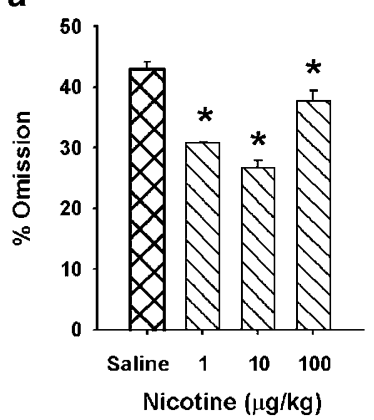

b

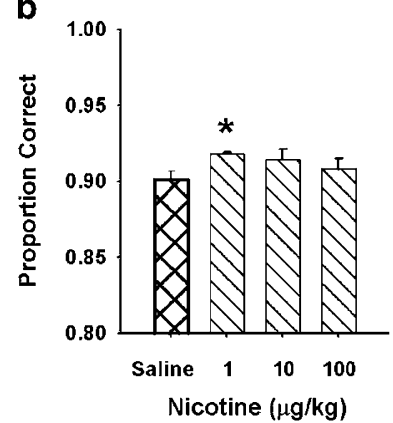

C

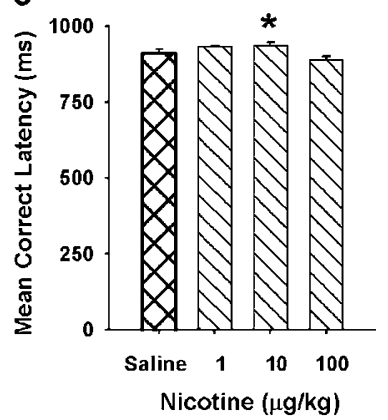

Figure 2 Effects of nicotine on the performance of drug-naive mice in the modified 5-CSR task. Mice were trained specifically for this study and as such were nicotine naive. The mice were separated into four groups in a counter-balanced design and given saline for three prior training sessions (Thursday, Friday, and Monday), followed by their allocated dose for 4 consecutive days (Tuesday-Friday). Every dose of ( - )nicotine examined significantly reduced \% omissions (a), with I $\mu \mathrm{g} / \mathrm{kg}$ increasing proportion correct (b). The $10 \mu \mathrm{g} / \mathrm{kg}$ dose of (-)nicotine produced a significant increase in mean correct latency (c). Doses of nicotine that produced significant effects compared to saline on these measures are marked $(* p<0.05)$, with data shown as mean \pm SEM.

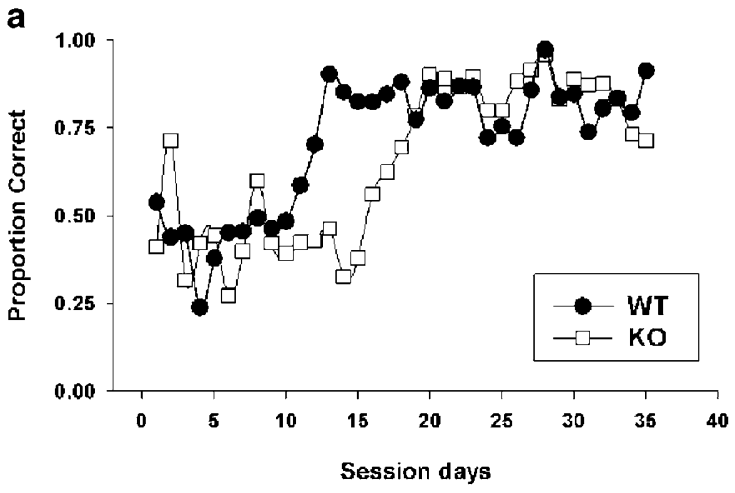

C

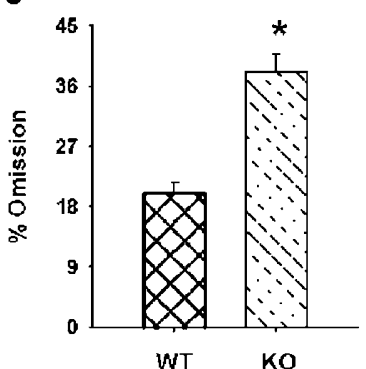

d

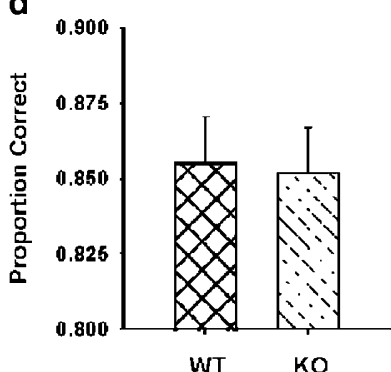

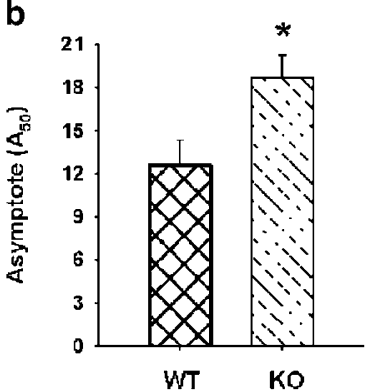

$\mathbf{e}$

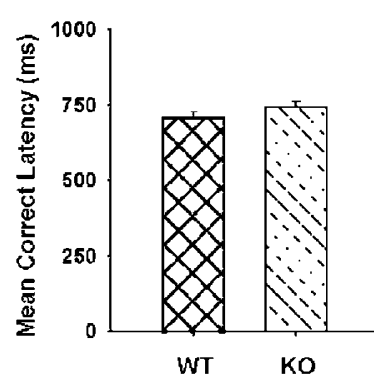

Figure 3 Effects of $\alpha 7 \mathrm{nAChR}$ KO on mouse performance of the 5-CSR task. The $\alpha 7 \mathrm{nAChR}$ KO mice had impaired acquisition as shown in (a), with data shown as proportion correct across session days for one representative subject from each group, and (b) the mean time taken by each group to reach halfway to asymptote $\left(A_{50}\right) . \alpha 7$ nAChR KO mice were also impaired in asymptotic performance of the task, as measured by \% omissions (c). Proportion correct (d), and mean correct latency (e) are also shown but were unaffected by removal of this receptor in the standard task. *Significant difference to that of the controls $(p<0.05)$, with data shown as mean \pm SEM.

resolved. As there are no commercially available $\alpha 7$ nAChR selective agonists or totally suitable antagonists we examined whether ablation of the $\alpha 7 \mathrm{nAChR}$ would have any detrimental effects on the performance of mice in the 5-CSR task. As Figure 3a shows, $\alpha 7 \mathrm{KO}$ mice took significantly longer to acquire the task than their age-matched WT littermates, with the time taken to reach $50 \%$ of asymptotic performance $\left(\mathrm{A}_{50}\right)$ being approximately 5 days longer (Figure $3 \mathrm{~b})(\mathrm{F}(1,12)=4.763, p=0.05)$. After attaining acquisition criteria and asymptotic performance, the $\alpha 7 \mathrm{KO}$ mice exhibited significantly higher levels of \% omissions (Figure 3c). A two-factor
ANOVA for repeated measures with genotype and day as between-subject factors yielded significant main effects of genotype on $\%$ omissions $(\mathrm{F}(1,36)=7.67$, $p<0.05)$ and day on proportion correct $(\mathrm{F}(1,36)=4.501$, $p=0.009)$. There were no significant effects of genotype on proportion correct (Figure 3d) or mean correct latency (Figure 3e).

\section{$\alpha 7$ nAChR Genotyping and $\left[{ }^{3} \mathrm{H}\right]$ MLA Binding}

To validate the behavioral deficits observed for the $\alpha 7 \mathrm{KO}$ mice, genotyping was performed, and a radioligand binding 
assay established using the putatively $\alpha 7 \mathrm{nAChR}$ selective antagonist $\left[{ }^{3} \mathrm{H}\right] \mathrm{MLA}$. Genotyping was conducted with $\alpha 7$ nAChR-specific primers that identified WT and disrupted alleles. These studies confirmed that the mice used were of the appropriate genotype (data not shown). Verification of the absence of $\alpha 7 \mathrm{nAChRs}$ at the protein level was obtained by establishing a $\left[{ }^{3} \mathrm{H}\right]$ MLA binding assay. Using $\mathrm{P}_{2}$ synaptosomal membranes prepared from normal mice and a range of cholinergic drugs, there was a concentrationdependent inhibition of $\left[{ }^{3} \mathrm{H}\right]$ MLA binding, with the following rank order of potency; MLA $>$ epibatidine $>d$ tubocurarine $=$ nicotine (Figure $4 \mathrm{a})$. The affinity $\left(K_{\mathrm{D}}\right)$ of MLA was $1.31 \pm 0.35 \mathrm{nM}(\mathrm{nH}=0.81 \pm 0.02 ; n=4)$, with $K_{\mathrm{i}}$ values of $167 \pm 106 \mathrm{nM}(\mathrm{nH}=1.46 \pm 0.14 ; n=3)$ for epibatidine, $1.80 \pm 0.07 \mu \mathrm{M}(\mathrm{nH}=1.48 \pm 0.44 ; n=3)$ for d-tubocurarine, and $1.41 \pm 0.82 \mu \mathrm{M}(\mathrm{nH}=1.06 \pm 0.09 ; n=3)$ for nicotine. For $\alpha 7 \mathrm{KO}$ mice and their WT littermates, each brain was treated individually. As Figure $4 \mathrm{~b}$ clearly shows, in WT littermates' specific $\left[{ }^{3} \mathrm{H}\right] \mathrm{MLA}$ binding was approximately $60 \%$ of total binding, whereas no specific binding was observed for the $\alpha 7 \mathrm{KO}$ mice.
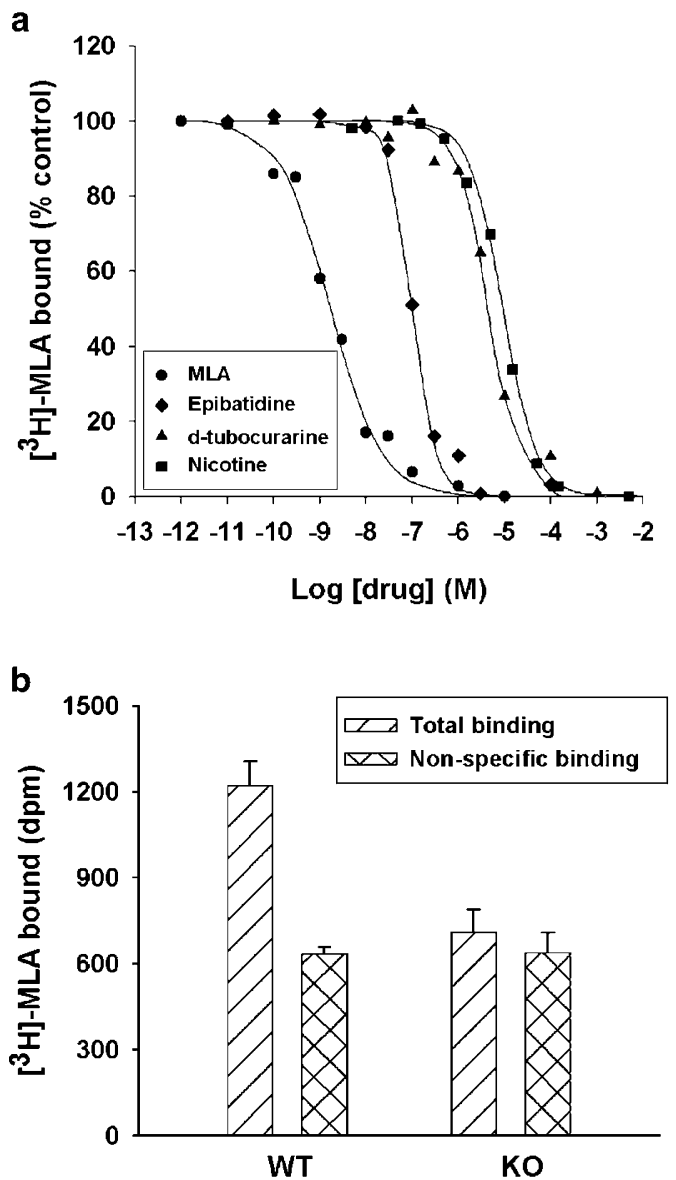

Figure $\left.4{ }^{3} \mathrm{H}\right] \mathrm{MLA}$ binding in $\mathrm{P}_{2}$ synaptosomal brain membranes from $W T$ and $\alpha 7 \mathrm{KO}$ mice. (a) Concentration-dependent inhibition of $\left[{ }^{3} \mathrm{H}\right] \mathrm{MLA}$ $(2 \mathrm{nM})$ binding to $\mathrm{P}_{2}$ synaptosomal brain membranes from WT animals by a range of cholinergic drugs. (b) The level of specific $\left.{ }^{3} \mathrm{H}\right] \mathrm{MLA}$ binding in $\mathrm{P}_{2}$ membranes prepared from individual WT control and transgenic mice ( $n=4$ per group) is shown. Clear specific $\left[{ }^{3} \mathrm{H}\right] \mathrm{MLA}$ binding was observed for WT animals, which is absent in $\alpha 7 \mathrm{KO}$ mice.

\section{DISCUSSION}

This is the first study in normal mice to demonstrate nicotine-induced improvements in sustained attention. These results support the hypothesis which suggests that the nicotine-induced improvement in attention in normal humans is characterized by a reduction in omission levels, and by an increase in proportion correct. Moreover, our demonstration that $\alpha 7 \mathrm{nAChR}$ KO mice exhibit higher omission levels in a less demanding version of the task implicates the $\alpha 7 \mathrm{nAChR}$ in attentional function.

In humans, the CPT has been routinely used to evaluate attentional performance (White and Levin, 1999; Shytle et al, 2002). In normal human subjects, nicotine administration has consistently been shown to enhance attention by reducing omissions (Levin et al, 1998). This is consistent with the hypothesis of Mancuso et al (1999), whereby the nicotine-induced improvement in attention is a consequence of nicotine acting to lock the brain into the attentional processing mode and so there are fewer lapses in attention', hence fewer errors of omission might be expected. However, an improvement in accuracy (proportion correct) following nicotine administration has also been observed in subjects displaying impaired attentional function, associated with schizophrenia, Alzheimer's disease, and attention deficit hyperactivity disorder (White and Levin, 1999; Shytle et al, 2002; Yang et al, 2002). The 5-CSR task was developed to examine sustained attention in rodents (Carli et al, 1983) and is regarded as being analogous to the CPT (Jones and Higgins, 1995). This task has been used extensively with rats, with nicotine generally showing an improvement in attention, but only when lesions or specific task challenges have been introduced to impair performance (Mirza and Stolerman, 1998; Grottick and Higgins, 2000; Stolerman et al, 2000; Mirza and Bright, 2001; Hahn et al, 2002, 2003a, b; Grottick et al, 2003). A consistent demonstration of a nicotine-induced facilitation of attention in unimpaired rats, unlike observations in humans (Levin et al, 1998), has proven challenging (Mirza and Bright, 2001; Terry et al, 2002). While widely used with rats, the 5-CSR task was only comparatively recently modified for use in mice (Humby et al, 1999), with no reports to date, on the effects of nicotine. Our initial studies indicated that the lack of effect of nicotine in mice may have been due to a 'ceiling effect' (data not shown), a feature commonly observed for rats (Grottick and Higgins, 2000; Hahn et al, 2002). Modification of the task by introducing the wide array and a variable ITI (this latter alteration minimizes the possibility of mice using any temporal mediating strategies), resulted in an increase in \% omissions and a reduction in proportion correct. These data clearly show that the performance of mice is not impaired when tested in the larger rat nine-hole operant chambers and so a reduction in box size, as used by Humby et al (1999), is not a prerequisite. Four groups of mice, previously exposed to different doses of nicotine, were given a 3-week washout period with saline to ensure a return to prestudy baseline performance. These mice were then tested in the modified task and given different doses of nicotine (Figure 1), based upon previous rodent and human studies (Muir et al, 1995; Grobe et al, 1998; Stolerman et al, 2000; Mirza and Bright, 2001). The $3 \mu \mathrm{g} / \mathrm{kg}$ dose of nicotine 
produced a clear improvement in performance, with a significant reduction in percent omissions and a concomitant increase in proportion correct. As nicotine administration is known to alter nAChR density (Gentry and Lukas, 2002), confirmation that the observed improvements in sustained attention were not merely a consequence of increased receptor number, required nicotine to be examined in drug-naive mice. Therefore, a new study was conducted using a modified dose range that took cognizance of the improvements seen at $3 \mu \mathrm{g} / \mathrm{kg}$ of nicotine. This study revealed a significant enhancement in the performance of drug-naive mice that were administered a $1 \mu \mathrm{g} / \mathrm{kg}$ dose of nicotine. The doses of nicotine that improved attention in mice in the present studies are consistent with those reported to improve attention in normal humans (Levin et al, 1998; Heishman and Henningfield, 2000; Min et al, 2001). In contrast, studies in rats have generally required higher doses of nicotine and the inclusion of lesions or task challenges (Muir et al, 1995; Mirza and Stolerman, 1998; Stolerman et al, 2000; Hahn et al, 2002, 2003a, b; Grottick et al, 2003). In addition, whereas nicotine reduced omission levels in ostensibly normal mice in the current study, and previously in normal human subjects (Levin et al, 1998), in rats, the most consistent manifestation of an improvement in attention was an increase in accuracy (Mirza and Stolerman, 1998; Hahn et al, 2002). The reasons underlying these different effects of nicotine on omissions in rodents have yet to be clearly defined. One possible explanation is that in rats, the lack of effect of nicotine on omissions may be due to a floor effect as baseline omissions are already $<10 \%$, whereas in mice they are approximately 20\% (Inglis et al, 2001; Spratt et al, 2001). This difference in omission levels cannot be attributed simply to the fact that mice were tested in apparatus commonly used for rats, as when the apparatus was scaled down, omission levels were still about 20\% (Humby et al, 1999). Therefore the reduction observed in omissions in mice is consistent with the nicotine-induced improvement in attention hypothesis proposed by Mancuso et al (1999).

While it appears that the 1 and $3 \mu \mathrm{g} / \mathrm{kg}$ doses of nicotine enhance sustained attention, at higher doses the physiological effects become increasingly complex (Picciotto, 2003; see Figure 5 for schematic representation). Between 10 and $100 \mu \mathrm{g} / \mathrm{kg}$ the overall trend continues to be that of a reduction in omissions, but with no effect on proportion correct. In contrast, at $300 \mu \mathrm{g} / \mathrm{kg}$, nicotine increased proportion correct without altering \% omissions. As this dose also reduced mean correct latency, this suggests the increase in accuracy may reflect psychomotor stimulation (Grottick and Higgins, 2000), with these mice consequently not attending to the cue array any more than control subjects. This would be consistent with nicotine being reported to produce motoric excitation at 125 and $250 \mu \mathrm{g} / \mathrm{kg}$ in mice (Nordberg and Bergh, 1985). Further increases in nicotine dose have been shown to lead to motoric inhibition and hypothermia (Marks et al, 1983; Figure 5).

Despite a plethora of evidence demonstrating nicotineinduced improvements in attention in different species, there has been no definitive identification of which nAChR subtype(s) are responsible. However, several studies indicate that the $\alpha 7 \mathrm{nAChR}$ appears crucial in maintaining one aspect of attentional function, namely sensory gating (Stevens et al, 1996, 1998; Simosky et al, 2001). Schizophrenics have poor sensory gating with a reduction in the P50 auditory evoked potential (Waldo et al, 1995). This deficiency has been linked to chromosome 15, in a region proximal to the $\alpha 7$ locus (Freedman et al, 1997). Moreover, the DBA/2 mouse strain, which has a natural reduction in $\alpha 7$ nAChR density, show sensory gating deficits (Stevens et al, 1996), that can be ameliorated by treatment with the $\alpha 7$ partial agonist DMXBA (GTS-21; Stevens et al, 1998; Simosky et al, 2001) and atypical antipsychotics (Simosky et al, 2003). DMXBA also attenuated the sensory gating deficits observed in rats that were reared in isolation (O'Neill et al, 2003), an animal neuro-developmental model of schizophrenia (Geyer et al, 1993). Furthermore, both DMXBA (Kem, 2000), and the full $\alpha 7 \mathrm{nAChR}$ agonist ARR17779 (Mullen et al, 2000), are able to replicate the beneficial effects observed with nicotine on working memory (Felix and Levin, 1997; Levin and Simon, 1998). In contrast, and perhaps somewhat surprisingly, recent studies in rats showed that AR-R17779 had no effect on attention in the 5-CSR task (Grottick and Higgins, 2000; Grottick et al, 2003; Hahn et al, 2003a). To date, independent evaluation of these agents is not possible as these compounds are not commercially available. Similarly, investigation of the $\alpha 7 \mathrm{nAChR}$ subtype using the selective antagonists $\alpha$-bungarotoxin and methyllycaconitine has proven difficult as the former is a large peptide which does not cross the blood-brain barrier, while there is now some debate over the selectivity of the latter (Mogg et al, 2002). Therefore, we chose to investigate the role of the $\alpha 7 \mathrm{nAChR}$

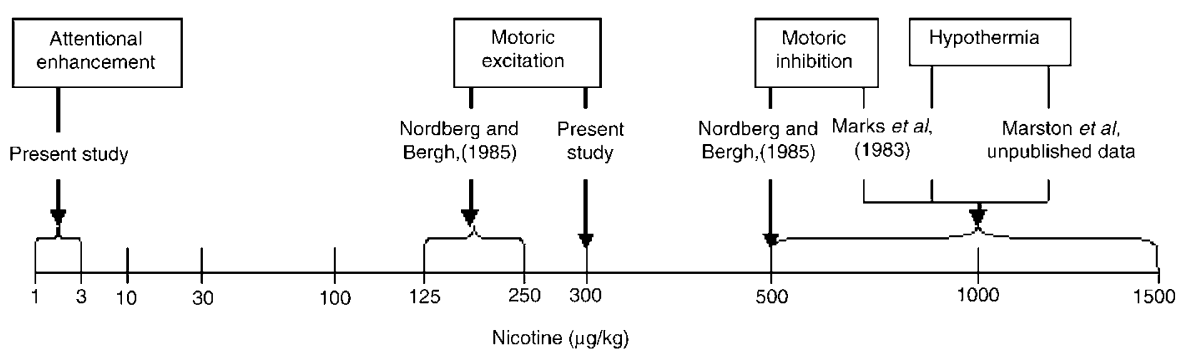

Figure 5 Schematic representation of nicotine-induced behavioral effects in mice. Nicotine exerts both cognitive and physiological effects that are largely dose dependent. The present study suggests that low doses of nicotine $(\mathrm{I}-3 \mu \mathrm{g} / \mathrm{kg})$ produce improvements in attention. Higher doses appear to reduce mean correct latency, suggesting an enhancement of motoric capabilities, consistent with previous studies (Nordberg and Bergh, I985). Doses of nicotine of $500 \mu \mathrm{g} / \mathrm{kg}$ and above inhibit motoric responses, with hypothermic effects observed. A further increase to $5 \mathrm{mg} / \mathrm{kg}$ has been shown to induce seizures in mice (Damaj et al, 1999). 
in attention in mice by studying $\alpha 7 \mathrm{KO}$ animals (OrrUrtreger et al, 1997) in the 5-CSR task. Even in the simple version of the 5-CSR task, the $\alpha 7 \mathrm{KO}$ mice had a clear deficit in attention, with omission levels significantly increased when compared to WT littermates. The absence of the $\alpha 7$ nAChR in the KO mice was verified by genotyping and radioligand binding studies using $\left[{ }^{3} \mathrm{H}\right]$ MLA. For WT mice, the $K_{\mathrm{D}} / K_{\mathrm{i}}$ values of the drugs examined in the $\left[{ }^{3} \mathrm{H}\right] \mathrm{MLA}$ binding assay were consistent with previous studies (Whiteaker et al, 1999). It is possible that the deficiencies observed are attributable to developmental problems that are a consequence of $\alpha 7 \mathrm{nAChR} \mathrm{KO}$, although these animals do have an ostensibly normal appearance; with standard growth, survival, gait, anatomy, and no nervous system abnormalities (Orr-Urtreger et al, 1997). In addition, Paylor et al (1998) reported no differences in the behavioral phenotype of $\alpha 7$ nAChR KO mice and their WT littermates when subjected to a battery of behavioral tests, including contextual and auditory fear conditioning, spatial learning in the Morris water maze, and anxiety tests. However, unexpectedly it was noted that the mice did not exhibit sensory gating deficits in the PPI paradigm (Paylor et al, 1998), although this result could have been confounded by the use female mice. It is conceivable that compensatory mechanisms, such as alterations in nAChR density, distribution, and/or receptor subtype, may result in gene KO studies producing fundamentally different results from that observed in traditional pharmacological studies. However, Orr-Urtreger et al (1997) did not detect differences in high affinity nicotinic binding sites in these $\alpha 7$ nAChR KO mice. The development of the modified 5-CSR task should allow confirmation of the $\alpha 7 \mathrm{nAChR}$ KO data, if and when, $\alpha 7$ selective agonists become available and we can then address whether species differences exist between rats and mice. In addition, future studies will address whether nicotine can improve the performance of $\alpha 7$ nAChR KO mice in this modified 5-CSR task and/or whether a similar effect is observed in $\alpha 7 \mathrm{nAChR}$ heterozygous mice.

In conclusion, modifying the 5-CSR task for mice impaired baseline performance and enabled the demonstration of an enhancement in sustained attention following nicotine administration. Moreover, we have also shown that $\alpha 7 \mathrm{nAChR}$ KO mice have a profound deficit in attention that was observed without increasing task difficulty. Therefore, it is conceivable that the $\alpha 7 \mathrm{nAChR}$ plays a role in nicotineinduced improvements in sustained attention.

\section{ACKNOWLEDGEMENTS}

We thank Dr LE Kerr, Mrs N Logan, and Mrs J McLuckie for their assistance and helpful comments during these studies and in the preparation of this manuscript. This work was funded by a research grant from the Fujisawa Pharmaceutical Company Limited (Osaka, Japan).

\section{REFERENCES}

Bates T, Mangan G, Stough C, Corballis P (1995). Smoking, processing speed and attention in a choice reaction time task. Psychopharmacology 120: 209-212.
Broad LM, Felthouse C, Zwart R, McPhie GI, Pearson KH, Craig PJ et al (2002). PSAB-OFP, a selective alpha 7 nicotinic receptor agonist, is also a potent agonist of the 5-HT3 receptor. Eur J Pharmacol 452: 137-144.

Carli M, Robbins TW, Evenden JL, Everitt BJ (1983). Effects of lesions to ascending noradrenergic neurones on performance of a 5-choice serial reaction task in rats; implications for theories of dorsal noradrenergic bundle function based on selective attention and arousal. Behav Brain Res 9: 361-380.

Chapman PF (2002). Giving drugs to knockout mice: can they do that? Trends Neurosci 25: 277-279.

Clarke PB, Schwartz RD, Paul SM, Pert CB, Pert A (1985). Nicotinic binding in rat brain: autoradiographic comparison of $\left[{ }^{3} \mathrm{H}\right]$ acetylcholine, $\left[{ }^{3} \mathrm{H}\right]$ nicotine, and $\left[{ }^{125} \mathrm{I}\right]$-alpha-bungarotoxin. $\mathrm{J} \mathrm{Neu}$ rosci 5: 1307-1315.

Cornblatt BA, Keilp JG (1994). Impaired attention, genetics, and the pathophysiology of schizophrenia. Schizophr Bull 20: 31-46.

Cullum CM, Harris JG, Waldo MC, Smernoff E, Madison A, Nagamoto HT et al (1993). Neurophysiological and neuropsychological evidence for attentional dysfunction in schizophrenia. Schizophr Res 10: 131-141.

Damaj MI, Glassco W, Dukat M, Martin BR (1999). Pharmacological characterization of nicotine-induced seizures in mice. J Pharmacol Exp Ther 291: 1284-1291.

Davis DHJ, Lukas RJ, Peng JH, Kelly JS, Finlayson K (2000). Characterisation of $\left[{ }^{3} \mathrm{H}\right]$-methyllycaconitine binding sites in rat brain tissue and cells stably expressing the human alpha-7 nicotinic receptor. Eur J Neurosci 12: 374.

Felix R, Levin ED (1997). Nicotinic antagonist administration into the ventral hippocampus and spatial working memory in rats. Neuroscience 81: 1009-1017.

Finlayson K, McLuckie J, Hern J, Aramori I, Olverman HJ, Kelly JS (2001). Characterisation of $\left[{ }^{125} \mathrm{I}\right]$-apamin binding sites in rat brain membranes and HE293 cells transfected with SK channel subtypes. Neuropharmacology 41: 341-350.

Freedman R, Coon H, Myles-Worsley M, Orr-Urtreger A, Olincy A, Davis A et al (1997). Linkage of a neuropsychological deficit in schizophrenia to a chromosome 15 locus. Proc Natl Acad Sci USA 94: 587-592.

Gentry CL, Lukas RJ (2002). Regulation of nicotinic acetylcholine receptor numbers and function by chronic nicotine exposure. Curr Drug Target CNS Neurol Disord 1: 359-385.

Geyer MA, Wilkinson LS, Humby T, Robbins TW (1993). Isolation rearing of rats produces a deficit in prepulse inhibition of acoustic startle similar to that in schizophrenia. Biol Psychiatry 34: 361-372.

Gotti C, Carbonnelle E, Moretti M, Zwart R, Clementi F (2000). Drugs selective for nicotinic receptor subtypes: a real possibility or a dream? Behav Brain Res 113: 183-192.

Grobe JE, Perkins KA, Goettler-Good J, Wilson A (1998). Importance of environmental distractors in the effects of nicotine on short-term memory. Exp Clin Psychopharmacol 6: 209-216.

Grottick AJ, Haman M, Wyler R, Higgins GA (2003). Reversal of a vigilance decrement in the aged rat by subtype-selective nicotinic ligands. Neuropsychopharmacology 28: 880-887.

Grottick AJ, Higgins GA (2000). Effect of subtype selective nicotinic compounds on attention as assessed by the five-choice serial reaction time task. Behav Brain Res 117: 197-208.

Hahn B, Sharples CG, Wonnacott S, Shoaib M, Stolerman IP (2003a). Attentional effects of nicotinic agonists in rats. Neuropharmacology 44: 1054-1067.

Hahn B, Shoaib M, Stolerman IP (2002). Nicotine-induced enhancement of attention in the five-choice serial reaction time task: the influence of task demands. Psychopharmacology 162: 129-137.

Hahn B, Shoaib M, Stolerman IP (2003b). Involvement of the prefrontal cortex but not the dorsal hippocampus in the 
attention-enhancing effects of nicotine in rats. Psychopharmacology 168: 271-279.

Heishman SJ, Henningfield JE (2000). Tolerance to repeated nicotine administration, subjective and physiological responses in nonsmokers. Psychopharmacology 152: 321-333.

Humby T, Laird FM, Davies W, Wilkinson LS (1999). Visuospatial attentional functioning in mice: interactions between cholinergic manipulations and genotype. Eur J Neurosci 11: 2813-2823.

Inglis WL, Olmstead MC, Robbins TW (2001). Selective deficits in attentional performance on the 5-choice serial reaction time task following pedunculopontine tegmental nucleus lesions. Behav Brain Res 123: 117-131.

Jones DN, Higgins GA (1995). Effect of scopolamine on visual attention in rats. Psychopharmacology 120: 142-149.

Kem WR (2000). The brain alpha7 nicotinic receptor may be an important therapeutic target for the treatment of Alzheimer's disease: studies with DMXBA (GTS-21). Behav Brain Res 113: 169-181.

Le Novere N, Corringer PJ, Changeux JP (2002). The diversity of subunit composition in nAChRs: evolutionary origins, physiologic and pharmacologic consequences. J Neurobiol 53: 447-456.

Levin ED, Conners CK, Silva D, Hinton SC, Meck WH, March J et al (1998). Transdermal nicotine effects on attention. Psychopharmacology 140: 135-141.

Levin ED, Simon BB (1998). Nicotinic acetylcholine involvement in cognitive function in animals. Psychopharmacology 138: $217-230$

Maemoto T, Finlayson K, Olverman HJ, Akahane A, Horton RW, Butcher SP (1997). Species differences in brain adenosine $A_{1}$ receptor pharmacology revealed by the use of xanthine and pyrazolopyridine based antagonists. Br J Pharmacol 122: 12021208.

Mancuso G, Warburton DM, Melen M, Sherwood N, Tirelli E (1999). Selective effects of nicotine on attentional processes. Psychopharmacology 146: 199-204.

Marks MJ, Burch JB, Collins AC (1983). Genetics of nicotine response in four inbred strains of mice. J Pharmacol Exp Ther 226: 291-302.

Marston HM, Spratt C, Kelly JS (2001). Phenotyping complex behaviours: assessment of circadian control and 5-choice serial reaction learning in the mouse. Behav Brain Res 125: 189-193.

Min SK, Moon IW, Ko RW, Shain HS (2001). Effects of transdermal nicotine on attention and memory in healthy elderly nonsmokers. Psychopharmacology 159: 83-88.

Mirza NR, Bright JL (2001). Nicotine-induced enhancements in the five-choice serial reaction time task in rats are strain-dependent. Psychopharmacology 154: 8-12.

Mirza NR, Stolerman IP (1998). Nicotine enhances sustained attention in the rat under specific task conditions. Psychopharmacology 138: 266-274.

Mogg AJ, Whiteaker P, McIntosh JM, Marks M, Collins AC, Wonnacott S (2002). Methyllycaconitine is a potent antagonist of alpha-conotoxin-MII-sensitive presynaptic nicotinic acetylcholine receptors in rat striatum. J Pharmacol Exp Ther 302: 197-204.

Muir JL, Everitt BJ, Robbins TW (1995). Reversal of visual attentional dysfunction following lesions of the cholinergic basal forebrain by physostigmine and nicotine but not by the 5-HT3 receptor antagonist, ondansetron. Psychopharmacology 118: 82-92.

Mullen G, Napier J, Balestra M, DeCory T, Hale G, Macor J et al (2000). (-)-Spiro[1-azabicyclo[2.2.2] octane-3, $5^{\prime}$-oxazolidin- $2^{\prime}$ one], a conformationally restricted analogue of acetylcholine, is a highly selective full agonist at the alpha 7 nicotinic acetylcholine receptor. J Med Chem 43: 4045-4050.

Nordberg A, Bergh C (1985). Effect of nicotine on passive avoidance behaviour and motoric activity in mice. Acta Pharmacol Toxicol 56: 337-341.
O’Neill HC, Rieger K, Kem WR, Stevens KE (2003). DMXB, an alpha(7) nicotinic agonist, normalizes auditory gating in isolation-reared rats. Psychopharmacology 169: 332-339.

O'Neill MJ, Murray TK, Lakics V, Visanji NP, Duty S (2002). The role of neuronal nicotinic acetylcholine receptors in acute and chronic neurodegeneration. Curr Drug Target CNS Neurol Disord 1: 399-411.

Orr-Urtreger A, Goldner FM, Saeki M, Lorenzo I, Goldberg L, De Biasi $M$ et al (1997). Mice deficient in the alpha7 neuronal nicotinic acetylcholine receptor lack alpha-bungarotoxin binding sites and hippocampal fast nicotinic currents. J Neurosci 17: 9165-9171.

Paylor R, Nguyen M, Crawley JN, Patrick J, Beaudet A, OrrUrtreger A (1998). Alpha7 nicotinic receptor subunits are not necessary for hippocampal-dependent learning or sensorimotor gating: a behavioral characterization of Acra7-deficient mice. Learn Mem 5: 302-316.

Picciotto MR (2003). Nicotine as a modulator of behavior: beyond the inverted U. Trends Pharmacol Sci 24: 493-499.

Sambrook J, Russell DW (2001). Molecular Cloning: A Laboratory Manual, 3rd edn. New York: Cold Spring Harbor Laboratory Press.

Sanberg PR, Silver AA, Shytle RD, Philipp MK, Cahill DW, Fogelson HM et al (1997). Nicotine for the treatment of Tourette's syndrome. Pharmacol Ther 74: 21-25.

Shoaib M, Gommans J, Morley A, Stolerman IP, Grailhe R, Changeux JP (2002). The role of nicotinic receptor beta-2 subunits in nicotine discrimination and conditioned taste aversion. Neuropharmacology 42: 530-539.

Shytle RD, Silver AA, Wilkinson BJ, Sanberg PR (2002). A pilot controlled trial of transdermal nicotine in the treatment of attention deficit hyperactivity disorder. World J Biol Psychiatry 3: $150-155$.

Simosky JK, Stevens KE, Adler LE, Freedman R (2003). Clozapine improves deficient inhibitory auditory processing in $\mathrm{DBA} / 2$ mice, via a nicotinic cholinergic mechanism. Psychopharmacology 165: 386-396.

Simosky JK, Stevens KE, Kem WR, Freedman R (2001). Intragastric DMXB-A, an alpha7 nicotinic agonist, improves deficient sensory inhibition in DBA/2 mice. Biol Psychiatry 50: 493-500.

Spratt C, McQuatt NE, Sharkey J, Kelly JS, Marston HM (2001). Comparison of rats and mice in a serial reaction task. $\mathrm{Br}$ Neurosci Assoc Abstr 16: P490.3.

Stevens KE, Freedman R, Collins AC, Hall M, Leonard S, Marks MJ et al (1996). Genetic correlation of inhibitory gating of hippocampal auditory evoked response and alpha-bungarotoxin-binding nicotinic cholinergic receptors in inbred mouse strains. Neuropsychopharmacology 15: $152-162$.

Stevens KE, Kem WR, Mahnir VM, Freedman R (1998). Selective alpha7-nicotinic agonists normalize inhibition of auditory response in DBA mice. Psychopharmacology 136: 320-327.

Stolerman IP, Mirza NR, Hahn B, Shoaib M (2000). Nicotine in an animal model of attention. Eur J Pharmacol 393: 147-154.

Terry AV, Risbrough VB, Buccafusco JJ, Menzaghi F (2002). Effects of (+/-)-4-[[2-(1-methyl-2-pyrrolidinyl)ethyl]thio]phenol hydrochloride (SIB-1553A), a selective ligand for nicotinic acetylcholine receptors, in tests of visual attention and distractibility in rats and monkeys. J Pharmacol Exp Ther 301: 284-292.

Waldo M, Myles-Worsley M, Madison A, Byerley W, Freedman R (1995). Sensory gating deficits in parents of schizophrenics. Am J Med Genet 60: 506-511.

White HK, Levin ED (1999). Four-week nicotine skin patch treatment effects on cognitive performance in Alzheimer's disease. Psychopharmacology 143: 158-165. 
Whiteaker P, Davies ARL, Marks MJ, Blagbrough IS, Potter BVL, Wolstenholme AJ et al (1999). An autoradiographic study of the distribution of binding sites for the novel $\alpha 7$-selective nicotinic radioligand $\left[{ }^{3} \mathrm{H}\right]$-methyllycaconitine in the mouse brain. Eur $\mathrm{J}$ Neurosci 11: 2689-2696.

Yang YK, Nelson L, Kamaraju L, Wilson W, McEvoy JP (2002). Nicotine decreases bradykinesia-rigidity in haloperidol-treated patients with schizophrenia. Neuropsychopharmacology 27: 684-686.

Young JW, Spratt C, Marston HM, Finlayson K, Kelly JS, Sharkey J (2003). Effect of nicotine on visuo-spatial sustained attention in mice as measured by the 5-choice serial reaction time task. J Psychopharmacol 17(Suppl): pA64. 